INTERDISCIPLINARIA ARCHAEOLOGICA NATURAL SCIENCES IN ARCHAEOLOGY

\title{
Variation of $\mathrm{Ba} / \mathrm{Ca}$ and $\mathrm{Sr} / \mathrm{Ca}$ Response in Human Hard Tissue from Archaeological Series
}

\author{
Anna Pankowska ${ }^{a^{*}}$, David Milde ${ }^{b}$ Jana Bohunskáb \\ ${ }^{a}$ Department of Anthropology, Faculty of Arts, University of West Bohemia, Sedláčkova 38, Plzeň, 30614, Czech Republic \\ ${ }^{b}$ Department of Analytical Chemistry, Regional Centre of Advanced Technologies and Materials, Faculty of Science, Palacký University Olomouc, \\ 17. listopadu 12, 77146 Olomouc, Czech Republic
}

\section{ARTICLE INFO}

\section{Article history:}

Received: $2^{\text {nd }}$ May 2016

Accepted: $20^{\text {th }}$ December 2016

\section{Key words.}

barium

calcium

strontium

human skeletal tissue

LA ICP-MS

ICP-oa-TOF-MS

\begin{abstract}
$A B S T R A C T$
This study aims to assess how strontium, barium and calcium $\left({ }^{138} \mathrm{Ba} /{ }^{44} \mathrm{Ca}\right.$ and $\left.{ }^{88} \mathrm{Sr} /{ }^{44} \mathrm{Ca}\right)$ are incorporated into human hard tissue (enamel, dentin and bone). For this purpose we used laser ablation with inductively-coupled plasma mass spectrometry (LA ICP-MS). Human hard tissue from an archaeological series was analysed to determine isotope signals to investigate possible differences between enamel, dentine and bone. Significant variance in the ratios was identified by tissue type. The manner in which the type of hard tissue influences ${ }^{138} \mathrm{Ba} /{ }^{44} \mathrm{Ca}$ and ${ }^{88} \mathrm{Sr} /{ }^{44} \mathrm{Ca}$ ratios is discussed. Possible reasons for distinct isotopic responses are individual ways of metabolism, tissue mineral incorporation, and individual differences in the elements' absorption. The validity of dietary and migration studies, based on barium and strontium concentrations, are reconsidered. More than just for dietary and migration pattern reconstruction, this method serves as a chemometric tool for human skeletal remains' discrimination. Using a discriminant function, we found substantial differentiation in the hard tissues of investigated individuals.
\end{abstract}

\section{Introduction}

The analysis of strontium, barium and calcium in bone (Burton 1996; Burton, Wright 1995) and enamel (Sponheimer et al. 2005; Copeland et al. 2010) has been used to reconstruct diet (Szostek et al. 2009), weaning patterns (Austin et al. 2013; Balter, Simon 2006; Burton, Price 1990), trophic levels in wild animals (Balter 2004), migration (Arnay et al. 2009; Copeland et al. 2008; Lewis et al. 2014) and feeding strategies in herbivores (Sillen 1988).

Recently, laser ablation with inductively coupled plasma mass spectrometry (LA ICP-MS) has been used to detect the spatial distribution of $\mathrm{Sr}, \mathrm{Ca}$ and $\mathrm{Ba}$ in separate human skeletal tissues from archaeological samples (Alvira et al. 2010; Austin et al. 2013; Dolphin et al. 2005; Prohaska et al. 2002). Using LA ICP-MS, we can easily observe the differences between tissues and investigate the causes of these differences. Differences between bone and dental tissues

*Corresponding author. E-mail: pankowsk@ksa.zcu.cz (enamel and dentin) may reflect three possible factors, other than dietary or geographic differences. First of all, element ratios in bone, dentin and enamel may reflect the specific responses of each tissue to sampling (ablation). Second, ratios may differ due to the heterogeneity of each element within living tissue caused by an individual's development, specific way of metabolism, tissue mineral incorporation, differences in the elements' absorption or age-dependent changes (Dolphin et al. 2005) and diseases (Alvira et al. 2011; Gemmel et al. 2002; Malara et al. 2006). Third, each tissue is variably influenced by diverse post-mortem diagenetic alterations. Bone tissue decomposes more rapidly than enamel, which is known to be less susceptible to diagenesis (Copeland et al. 2008). However, enamel is not altogether resistant to diagenetic processes over longer time scales similar to that of fossilised remains in paleoanthropological contexts (Sponheimer, Lee-Thorp 2006).

It is necessary to consider the reliability of skeletal tissue analysis in the reconstruction of past diets. Are bones less suited for reliable isotope testing than dental tissue, and how are the differences between them to be interpreted? 
Differences between dental and bone tissue tests are expected. But how do we resolve the distinct isotopic signals between enamel and dentin? The different properties of each tissue type, the hardness and irregularity of their surfaces, combined with a lack of solid standard reference materials, can cause the different response of isotopic signals and misinterpretation of the date. The use of LA ICP-MS may provide a solution. This method enables the investigation of solid samples using a laser to ablate the isotopes into an inductively coupled plasma (ICP) source for the mass spectrometer and measure the signals of isotopes in their spatial distribution from various parts of the sample.

In this brief study we present our pilot research regarding the differences in isotopic responses of skeletal tissue to various external factors. The present study investigated ${ }^{88} \mathrm{Sr} /{ }^{44} \mathrm{Ca}$ and ${ }^{138} \mathrm{Ba} /{ }^{44} \mathrm{Ca}$ in three hard tissues (enamel, dentin and bone). We expect differences to be present between dental tissue and bone. Dentin formation follows enamel, therefore they should reflect similar ${ }^{88} \mathrm{Sr} /{ }^{44} \mathrm{Ca}$ and ${ }^{138} \mathrm{Ba} /{ }^{44} \mathrm{Ca}$ ratios, in spite of the dentin being partially remodelled during one's later life, contrary to bone. If this is not the case, then the variances relate to factors that are not related to diet or geography. What could cause such differences? How reliable then are studies based on the analysis of a single tissue type.

\subsection{Utility of $\mathrm{Sr} / \mathrm{Ca}$ and $\mathrm{Ba} / \mathrm{Ca}$ ratios in palaeodietary studies}

The ratio of strontium $(\mathrm{Sr})$ or barium $(\mathrm{Ba})$ to calcium (Ca) fixed into human bone and teeth hydroxyapatite is used to understand the dietary trophic level of past human populations (Burton, Price 2002). Higher concentrations of $\mathrm{Sr}$ and $\mathrm{Ba}$, and thus higher $\mathrm{Ba} / \mathrm{Ca}$ and $\mathrm{Sr} / \mathrm{Ca}$ ratios, observed in the skeletal tissue are the remarkable indicator of a plant-based diet (Burton 1996). On the other hand, a marine and meat-based diet decreases the value of both these ratios and also the $\mathrm{Ba} / \mathrm{Sr}$ ratio (Burton, Price 1990). Strontium can be used in this way for diet reconstruction because of its bio-purification when rising up through the trophic levels and is thus useful for estimating the proportion of meat and plant food in a diet through a comparison of human and animal skeletal tissue from the same site. The bones and teeth of humans who consume more plants should contain more strontium than those of meat-consumers or omnivores. Barium, similarly to strontium, reflects the trophic level. The amount of barium reflects certain aspects of a diet such as the consumption of marine sources and meat. Large differences in barium, but not in strontium, have been evidenced between marine and terrestrial archaeological bone (Burton 2007). The reason for this is the solubility of strontium. Strontium sulphate is soluble in environments rich in sulphate ions, i.e. in the ocean. Barium is not soluble, and is removed from the environment as insoluble barite $\left(\mathrm{BaSO}_{4}\right)$. Therefore the $\mathrm{Ba} / \mathrm{Ca}$ ratio is lower in a marine diet (Burton, 2007). Carnivores and consumers of a marine diet have generally lower $\mathrm{Ba} / \mathrm{Ca}$ ratios than herbivores. Calcium is a major component of skeletal tissue and its levels in humans are strongly regulated, with bone as the main mineral storage tissue. Animals and humans favourably intake calcium, therefore they have lower $\mathrm{Sr} / \mathrm{Ca}$ and $\mathrm{Ba} / \mathrm{Ca}$ ratios than the food they eat. However, this effect appears only in single component diets, multi-component diets do not show such simple correspondence. Even food with small amounts of calcium may decrease the $\mathrm{Sr} / \mathrm{Ca}$ ratio because calcium is preferentially absorbed. Yet absorption depends on the type of food and individual calcium metabolism (Reynard et al. 2011). In plants, calcium is necessary for growth and development. Some plants contain high levels of calcium (seeds, nuts, etc.), other plants such as grain (e.g. wheat) contain very low portions of calcium (Pharswan, Farswan 2011). Measurements of calcium content in microanalyses of skeletal tissue are also mainly done with the purpose of assessing the quality of archaeological material in terms of its diagenetic resistance (Allmäe et al. 2012). Diagenetic changes like calcium carbonate precipitation or decalcification should also be capable of reconstruction using the $\mathrm{Ca} / \mathrm{P}$ ratio.

\subsection{Limitation of $\mathrm{Sr} / \mathrm{Ca}$ and $\mathrm{Ba} / \mathrm{Ca}$ in palaeodietary studies}

The simple linearity between diet and alkaline elements incorporated in skeletal tissue is highly biased by: a) diagenetic contamination; b) local geographic environment; c) isotopic heterogeneity of a plant-based diet; d) individual variability; and c) a mixed diet (Burton, Price 2002). Diagenetic contamination is caused by many agents, e.g. chemical, mechanical, biological and physical factors (Burton, Price 2002) and the process of diagenesis consists of several mechanisms: dissolution, precipitation, absorption and recrystallization. Elevated levels of $\mathrm{Fe}, \mathrm{Mn}, \mathrm{Si}, \mathrm{Al}$ and $\mathrm{Ba}$ in fossil teeth indicate the formation of secondary minerals (Kohn et al. 1999; Patterson et al. 1991). Most common is the substitution of elements in the hydroxyapatite. Calcium may be substituted by $\mathrm{Sr}, \mathrm{Ba}, \mathrm{Mg}, \mathrm{Na}, \mathrm{U}$ and $\mathrm{Pb}$; these substitutions producing changes in the content and structure of the hydroxyapatite. Diagenetic changes in fossil samples can be determined using various methods such as FTIR, NMR and LA ICP-MS (Kang et al. 2004; Prohaska et al. 2002).

Barium, strontium and calcium are variably distributed in the subsoil and are geologically-specific (Burton et al. 2003). Their content in human tissue can reflect where the individual lived more than what he or she ate. Burton et al. (2003) recorded high variability of strontium and barium in soil samples in USA. Deviations among geographically different regions were significantly greater than local variations in skeletons. These variations can affect dietary comparisons among various sites (Burton et al. 2003). Other studies have used the $\mathrm{Ba} / \mathrm{Sr}$ ratio in teeth for the reconstruction of migration rather than for dietary investigation (Arnay et al. 2009; Brügmann et al. 2012).

Even though particular plants may be consumed by both animals and humans, they are absorbed differently, and will leave different trace mineral content in the skeletal and dental tissues of different species. Burton and Price (2002) 
present the variability of the dietary $\mathrm{Sr} / \mathrm{Ca}$ ratio among corn, nuts, potatoes and leaf vegetables (Burton, Price 2002, 165, Figure 8.2). They stress that differences in $\mathrm{Sr} / \mathrm{Ca}$ ratios do not show dietary plant/meat proportions, but rather the degree of browsing and grazing. Therefore low-calcium plants like some grains can display the same $\mathrm{Sr} / \mathrm{Ca}$ ratio as meat or marine food (Ezzo et al. 1995).

Strontium, barium and other trace elements' incorporation into skeletal tissue depends on dietary as well as geological processes (Darrah 2009). Other differences can be associated with individual metabolic function and incorporation such as inhalation and chemical exposure. Due to the occurrence of individual variation in trace element incorporation in human skeletal tissue, studies like Perrone et al. (2014) and Gonzalez-Rodriguez, Fowler (2013) used trace elements for species and individual classification and calculation of minimum number of individuals. These studies have great potential for forensic purposes.

The dietary $\mathrm{Sr} / \mathrm{Ca}$ ratio for mixed diets is not linear; the proportion of plant/meat diet composition is not binary, but rather continuous and highly individually variable. Some plants have more than ten times as much calcium and strontium as meat (Burton, Price 2002) and they have a greater effect on the element composition of connective tissue than meat does. Meat is noticeably up to $90 \%$ of its representation in the diet (Burton 2007, 447, Figure 14.2).
Only a pure plant or a pure meat diet is visible in the $\mathrm{Sr} / \mathrm{Ca}$ ratios in human tissue.

Comprehension of the variation of $\mathrm{Sr}, \mathrm{Ba}$ and $\mathrm{Ca}$ in human connective tissue and its causes is essential for our investigation. What the skeletal tissues can truly reflect is why do they differ from each other and which tissue is the most reliable indicator of diet.

\subsection{Subsistence strategy of Early Bronze Age population at Chrášt'any site}

The osteological sample originated from the Early Bronze Age site of Chrášt’any. Chrášt'any is situated on a small hill (203 m a.s.1.) in the Mojena River valley (194 m a.s.1.) in central Moravia, the eastern part of the Czech Republic (Figure 1). The local subsoil consists of Quaternary loess and loessic loam. The site was settled continually from the $2^{\text {nd }}$ half of the $3^{\text {rd }}$ millennium BC (Corded Ware Culture) till the early Middle Ages. Most finds from the site date from the Early Bronze Age (EBA) from 2200-1500 BC, a period characterized by oak and hornbeam woodlands, and hardwood floodplains of oak, ash and elm (Kočárová, Kočár 2010).

Groundwater at the site is neutral to slightly alkaline $\mathrm{pH} 7.0$ to 8.3) with a higher than the local average level of calcium, sodium and potassium cations. The area has high levels of strontium $\left(0.24\right.$ to $\left.1.22 \mathrm{mg} \cdot \mathrm{l}^{-1}\right)$ that probably originate in the

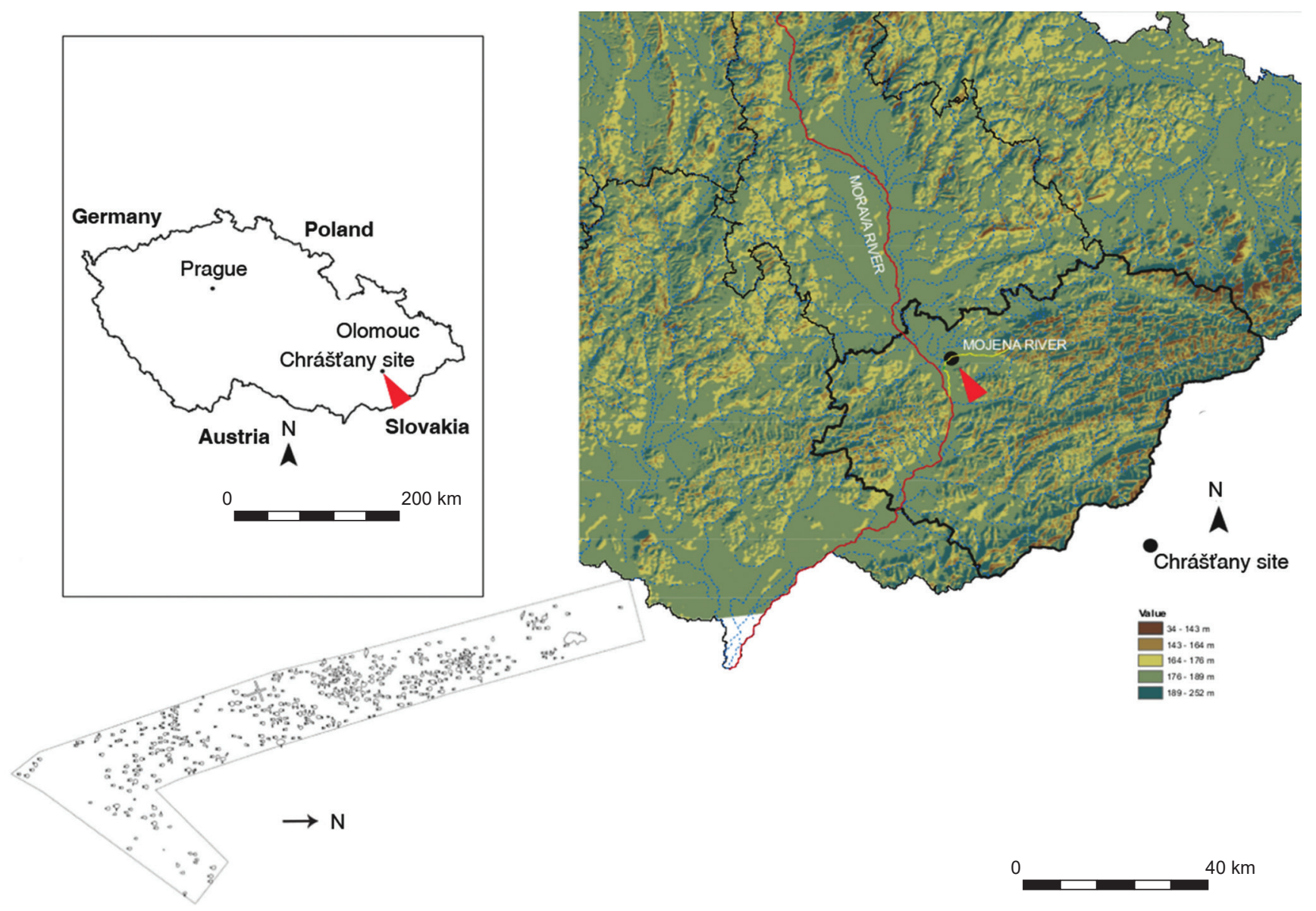

Figure 1. Chrášt’any site, Moravia, Czech Republic. Plan of the site by Martin Paulus (Archeologické centrum Olomouc). 
clayey sediments of the Menilite and Submenilite formations of the Ždánice Unit of the Carpathian Flysch Belt (Müller 1994).

Agriculture was the dominant subsistence strategy and the daily activity for most of the EBA population (Barker 1985). The distribution of grain storage pits at excavated sites is indicative of substantial agricultural activity. The storage pits at Chrášt'any were concentrated in clusters and used primarily for cereal (or pulse) crops and other food storage. Storage pits were dug in the loess, which is well suited for the dense networks of deep pits. The pits were concentrated in discrete areas of the settlement, and are thought to have been a valuable fixed asset of the community.

Macroremains of hulled wheat (einkorn and wild emmer) have been discovered in these storage pits (Kočárová, Kočár 2010). Zooarchaeological analyses have identified the remains of cattle, pigs, sheep or goats, and some dogs and horses. Hunted wild game included bear, roe deer, red deer, hare and pike. The bones of most farm animals, including dog, had been butchered and most likely modified by cooking. Young animals were butchered for meat, whilst older animals were exploited for milk, labour and breeding (Holub 2010). Animal bones were frequently used for tools such as awls and spear points. It is presumed that stored grain was only used for human consumption. Animals grazed outside the settlement and were slaughtered before winter so that they did not require winter feeding.

\section{Material and methods}

\subsection{Osteological sample}

The osteological material consists of six burials from five settlement features excavated at Chrášt’any (Paulus 2011). Two radiocarbon dates from sites with pit burials range from $3460 \pm 25 \mathrm{BP}$ to $3580 \pm 25 \mathrm{BP}$ (cal BC: $1804 \pm 55$ to $1938 \pm 30$, Weninger et al. 2007). Individuals were selected for analysis according to their preservation. All individuals were buried inside the settlement in storage pits scattered across the

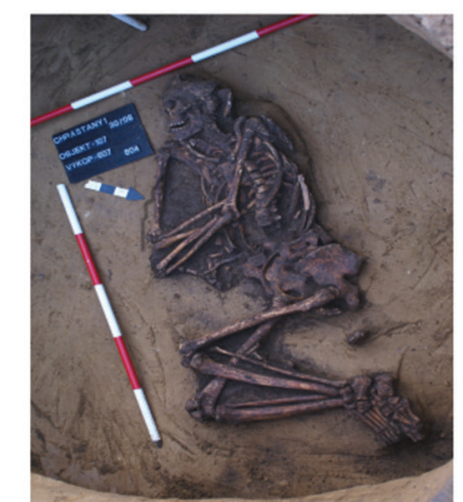

Individual 107/804 MALE

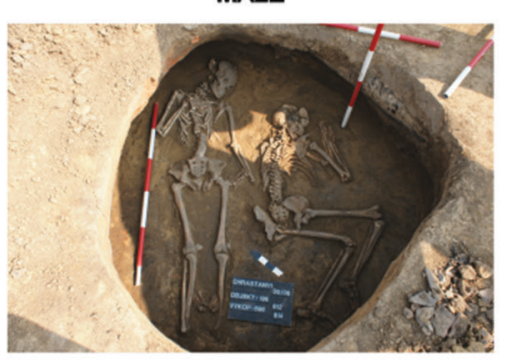

Individual 196/812 FEMALE

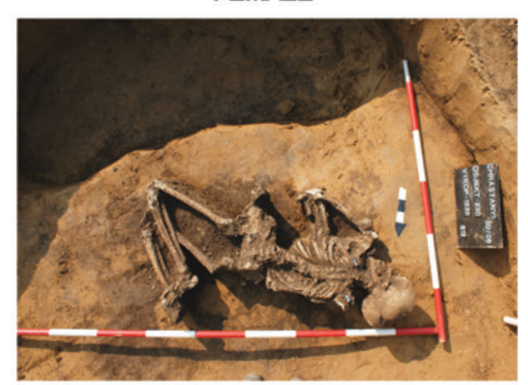

Individual 230/813 INDIFFERENT SEX
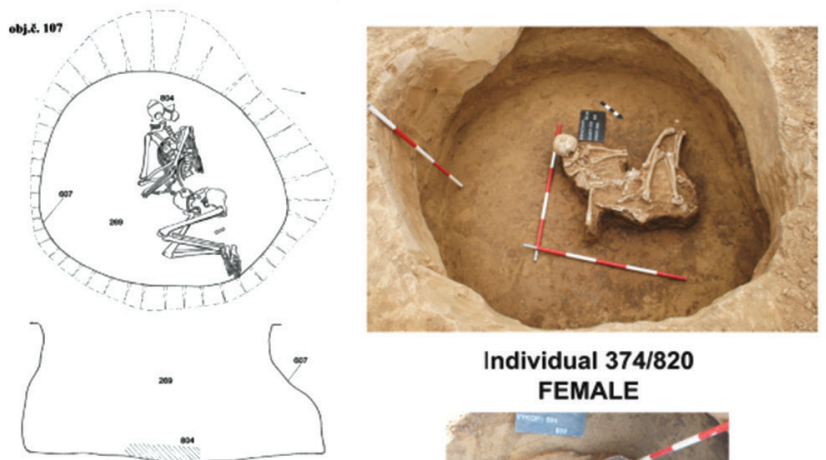

Individual 374/820 FEMALE

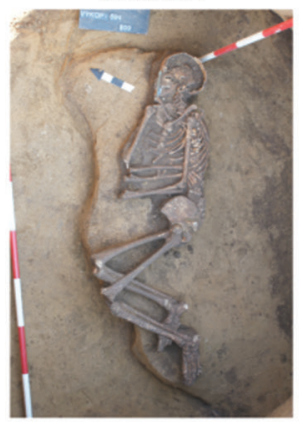

Individual 194/809 FEMALE

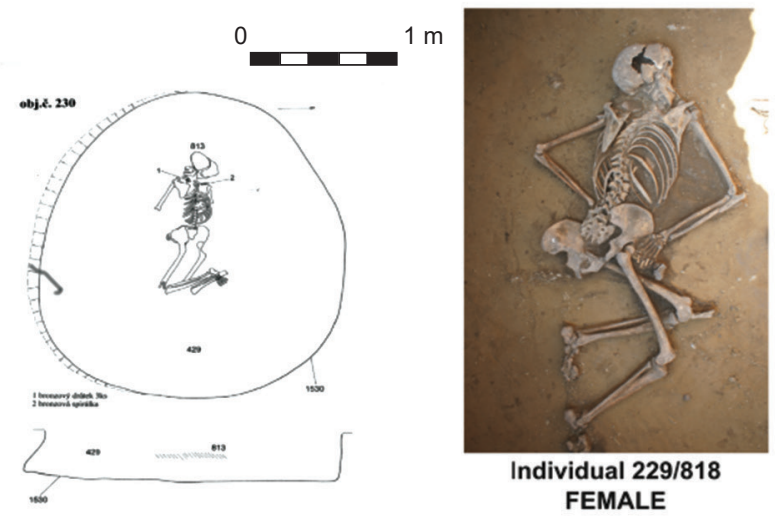

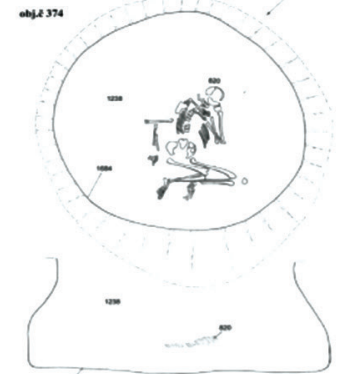

obs. 198
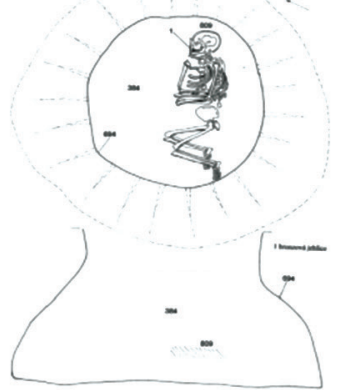

osse. 29

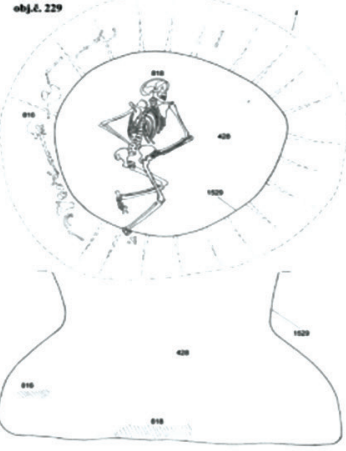

Figure 2. Settlement burials. Drawings of skeletons by Antonie Pešková (Archeologické centrum, Olomouc). 
Table 1. Sample under study.

\begin{tabular}{|c|c|c|c|c|c|}
\hline ID & Bone sample & Tooth sample & Sex & Age (yr) & $\mathrm{C}^{14}(\text { calBP })^{*}$ \\
\hline $107 / 804$ & femur & M1 sin (enamel, dentin) & male & $19-34$ & \\
\hline $196 / 812$ & femur & M2 dx (enamel, dentin) & female & $15-21$ & $3754 \pm 55$ \\
\hline $230 / 813$ & femur & M2 dx (enamel, dentin) & indiferent & adult & \\
\hline $374 / 820$ & femur & M1 sin (enamel, dentin) & female & $25-45$ & \\
\hline $194 / 809$ & femur & M1 dx (enamel, dentin) & female & $14-18$ & \\
\hline $229 / 818$ & femur & M3 sin (enamel, dentin) & female & $25-34$ & $3888 \pm 30$ \\
\hline Sus scrofaf. domestica & femur & & indiferent & adult & \\
\hline
\end{tabular}

* Laboratory code UGAMS\# 9503, 9504.

excavated area (Figure 2). Six human teeth (first or second molars) and six human bone samples taken from cortical part of their femoral midshaft, along with one pig bone (Sus scrofa f. domestica) were chosen for isotopic analysis (Table 1). Pigs often eat human waste and consume a diet similar to humans, and are the domesticated animals most likely to have lived locally (Bentley 2004). The isotopic content of their hard tissues should correspond to their geological and temporal context.

\subsection{Sample Preparation}

Bone and teeth samples were dry-cut (to prevent sorption) with a $200 \mathrm{~mm}$ diamond saw. Bones were cut across, teeth longitudinally. The samples were stabilized in $25 \mathrm{~mm}$ lenses filled with epoxy glue (Araldite 2020, Huntsman, Switzerland). The sample and epoxy were left to harden for two days at a temperature of $55^{\circ} \mathrm{C}$ on a heating plate (Stuart, Germany). After removal from their forms, samples were abraded, and washed with denatured alcohol.

Using LA ICP-MS, we analyzed standard reference materials and the samples of bones and teeth. We determined the part of the sample to be analyzed using a micro-camera and drew an ablation line on the sample (see Figure 3). The measuring time of one ablation line was set at $10 \mathrm{~s}$ (in this way, the mean intensity of isotopes was determined). In the case of measurement of the correlation between intensity (cps) and measuring time, 35-40 points were selected according to sample type, each measured for $1 \mathrm{~s}$ so that each measurement took $30-45 \mathrm{~s}$ and the mean value of background intensity was discounted from the intensity values of the isotopes of the sample.

\subsection{Elemental Analyses}

LA connected to the ICP-MS with Tygon tubing was used for the elemental analysis of all bone and teeth samples. The LA Analyte G2 (Photon Machines, USA) equipped with a HelEx ablation cell uses an argon fluoride excimer laser with
Figure 3. Example of the ablation line. Photo by J. Bohunská.
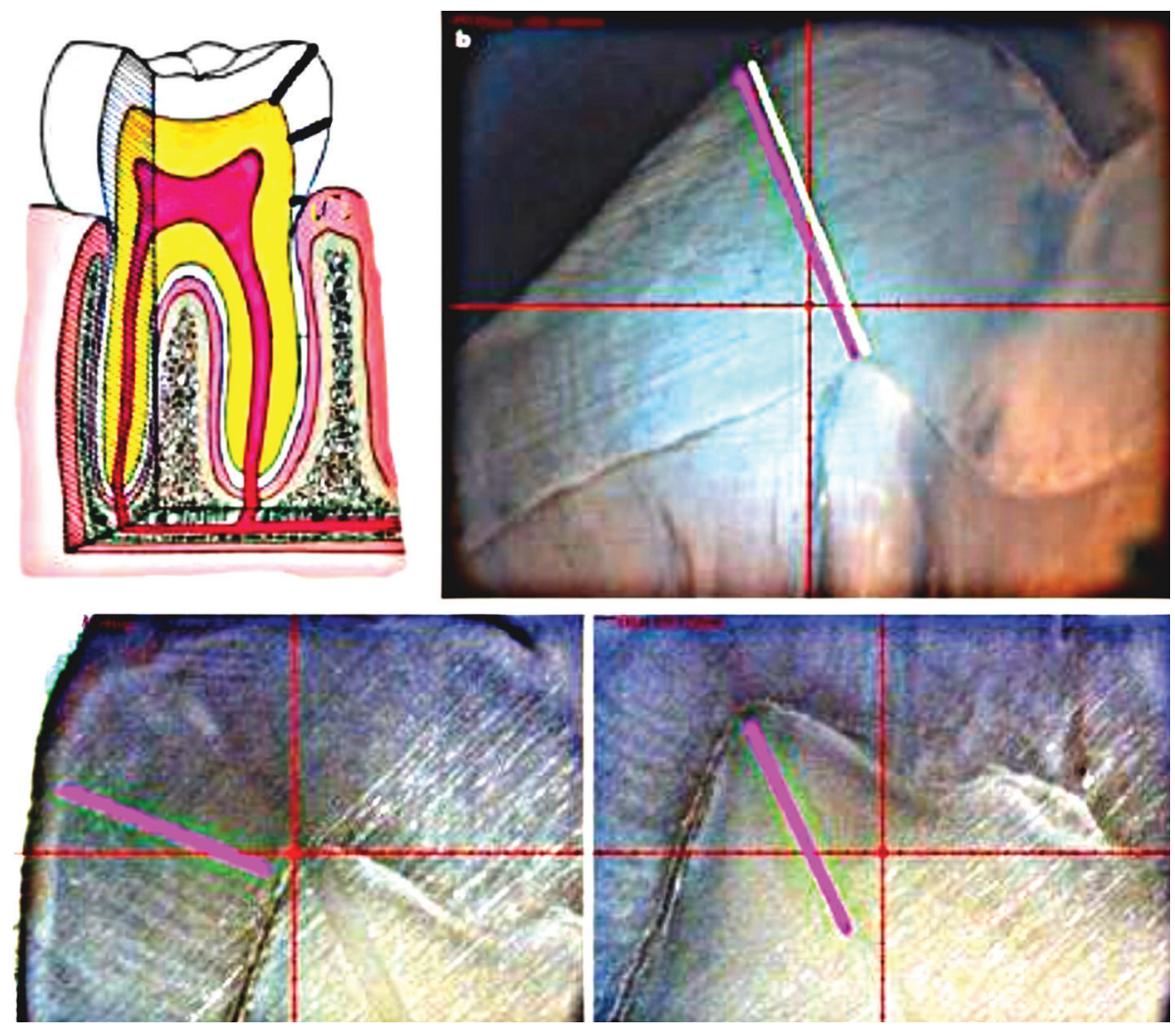
a wavelength of $193 \mathrm{~nm}$ and helium $(\mathrm{He}) 5.5$ is used as an ablation gas (Siad, Czech Republic). The following parameters were used: laser fluence of $7.4 \mathrm{~J} \mathrm{~cm}^{-2}$, pulse frequency of $10 \mathrm{~Hz}$, line of $50 \mu \mathrm{m}$ spots, scan speed of $30 \mu \mathrm{m} \mathrm{s}^{-1}$, He flow of $0.7 \mathrm{~L}$ $\mathrm{min}^{-1}$. Inductively coupled plasma with a time-of-flight mass spectrometer (ICP-TOF-MS) Optimass 9500 (GBC, Australia) was used to analyse ${ }^{43} \mathrm{Ca},{ }^{44} \mathrm{Ca},{ }^{86} \mathrm{Sr},{ }^{87} \mathrm{Sr},{ }^{88} \mathrm{Sr},{ }^{137} \mathrm{Ba},{ }^{138} \mathrm{Ba}$ isotopes. The instrument settings are summarized in Table 2. Optimization of the LA ICP-MS was performed using SRM 612 and 610 (NIST, USA). Mass calibration was achieved with ${ }^{7} \mathrm{Li}^{+},{ }^{115} \mathrm{In}^{+}$and ${ }^{238} \mathrm{U}^{+}$in above mentioned reference materials.

\subsection{Use of NIST SRM 1486 Bone Meal tablet}

We followed Uryu et al. (2003) when preparing the NIST

Table 2. Instrumental operating conditions for ICP-MS.

\begin{tabular}{lr}
\hline ICP source & \\
\hline RF power $(27.12 \mathrm{MHz})$ & $1200 \mathrm{~W}$ \\
Plasma gas flow rate & $0.51 \mathrm{~min}^{-1}$ \\
Auxiliary gas flow rate & $0.71 \mathrm{~min}^{-1}$ \\
Nebuliser gas flow rate & \\
Mass spectrometer & $-1250 \mathrm{~V}$ \\
Skimmer & $-1000 \mathrm{~V}$ \\
Extraction & $-900 \mathrm{~V}$ \\
Z1 & $-750 \mathrm{~V}$ \\
Y mean & $0 \mathrm{~V}$ \\
Y deflection & $-1290 \mathrm{~V}$ \\
Z lens mean & $0 \mathrm{~V}$ \\
Z lens deflection & $-190 \mathrm{~V}$ \\
Lens body & $150 \mathrm{~V}$ \\
Blanker & $650 \mathrm{~V}$ \\
Reflectron & $2450 \mathrm{~V}$ \\
Electron multipier gain & \\
\hline &
\end{tabular}

SRM 1486 Bone Meal tablet. Measured values of different isotopes' intensities in cps units, and correlation of intensities to measuring time were processed using the linear inversion method.

Different isotopes of reference samples SRM 610 and SRM 612 were measured with a laser beam $40 \mu \mathrm{m}, 50 \mu \mathrm{m}$ and $65 \mu \mathrm{m}$ thick. The intensity of the laser was $100 \%$ $\left(10.59 \mathrm{~J} / \mathrm{cm}^{2}\right)$, the frequency of its pulses $10 \mathrm{~Hz}$, speed of motion of the sample $30 \mu \mathrm{m} / \mathrm{s}$. The optimal diameter of the laser beam was $50 \mu \mathrm{m}$. Using Sr intensity from SRM 1486 reference material in a linear regression counted from SRM 610 and SRM 612, the calculated concentration of $\mathrm{Sr}$ was $2365.0 \mu \mathrm{g} / \mathrm{g}$. The certified concentration of $\mathrm{Sr}$ in the standard reference material SRM 1486 Bone Meal was $264 \pm 7 \mu \mathrm{g} / \mathrm{g}$ (Table 3). The significant difference between the certified and calculated value was given by a different type of material, i.e. the hardness of the glasses SRM 610 and SRM 612 , and the prepared tablet composed of a material similar to bone.

\subsection{Statistical Analysis}

Initially, ${ }^{88} \mathrm{Sr} /{ }^{44} \mathrm{Ca}$ and ${ }^{138} \mathrm{Ba} /{ }^{44} \mathrm{Ca}$ ratios were correlated in each separate tissue in each individual. This is necessary as both ratios reflect the same process. We used the nonparametric Spearman Correlation on data with non-normal distributions obtained from bone (Shapiro-Wilk Tests; $N=34 ; \mathrm{p} \leq 0.05$ ) and dentin (Shapiro-Wilk Tests; $\mathrm{N}=21 ; \mathrm{p} \leq 0.05$ ), and Pearson's Correlation on data with standard distributions obtained from enamel (Shapiro-Wilk Tests; $\mathrm{N}=22 ; \mathrm{p} \geq 0.05$ ). The second step used the Kruskal-Wallis test for independent samples. The null hypothesis was that the distribution of ${ }^{88} \mathrm{Sr} /{ }^{44} \mathrm{Ca}$ and ${ }^{138} \mathrm{Ba} /{ }^{44} \mathrm{Ca}$ is the same across the three categories of tissue (bone, dentin, enamel). Linear discriminant analyses (LDA) were carried out in order to identify the ratio intensities which best classify individuals. LDA was performed using the open source PAST software (Hammer et al. 2001) for $\mathrm{n}=25$. Univariate statistical analyses were undertaken with SPSS (version 22.0) software.

Table 3. Standard reference material.

\begin{tabular}{|c|c|c|c|c|c|c|}
\hline \multirow{2}{*}{ Element } & \multicolumn{2}{|c|}{ SRM* $^{*} 610$} & \multicolumn{2}{|c|}{ SRM $^{*} 612$} & \multicolumn{2}{|c|}{ SRM $^{*} 1486$} \\
\hline & \multicolumn{2}{|c|}{$\mathrm{mg} / \mathrm{kg}$} & \multicolumn{2}{|c|}{$\mathrm{mg} / \mathrm{kg}$} & \multicolumn{2}{|c|}{$\mu \mathrm{g} / \mathrm{g}$} \\
\hline $\mathrm{Ca}$ & & & & \multicolumn{2}{|c|}{$26.6 \pm 0.3^{1)}$} \\
\hline $\mathrm{Sr}$ & \multicolumn{2}{|c|}{$515.5 \pm 0.5$} & \multicolumn{2}{|c|}{$78.4 \pm 0.2$} & \multicolumn{2}{|c|}{$264 \pm 7$} \\
\hline $\mathrm{Ba}$ & \multicolumn{2}{|c|}{$453.5 \pm 37$} & \multicolumn{2}{|c|}{$38.6 \pm 2.6$} & & \\
\hline Isotope $^{* * *}$ & Average $(n=4)$ & RSD (\%) & Average $(n=4)$ & RSD (\%) & Average (7-16 s) & RSD (\%) \\
\hline${ }^{44} \mathrm{Ca}$ & 28461.1 & 2.1 & 24820.8 & 8.3 & 968652.4 & 4.6 \\
\hline${ }^{88} \mathrm{Sr}$ & 138448.5 & 4.3 & 26754.4 & 5.7 & 611055.0 & 4.8 \\
\hline${ }^{137} \mathrm{Ba}$ & 24260.7 & 3.4 & 2580.7 & 4.9 & 123695.1 & 5.2 \\
\hline${ }^{87} \mathrm{Sr}$ & 62041.0 & 7.1 & 10456.4 & 4.3 & 52499.9 & 6.0 \\
\hline${ }^{86} \mathrm{Sr}$ & 22627.1 & 2.0 & 7637.4 & 7.2 & 63520.8 & 4.7 \\
\hline${ }^{138} \mathrm{Ba}$ & 157092.6 & 4.0 & 14829.6 & 4.7 & 817909.2 & 4.5 \\
\hline
\end{tabular}

${ }^{*}$ Standard Reference Material (SRM); ${ }^{1)}$ in weight $\%$.

${ }^{* * *}$ Average cps of the measured isotopes and their RSD (\%) for SRM 610, SRM 612 a SRM 1486 ( $\mathrm{n}=$ number of measurements). 


\section{Results}

The correlation of ${ }^{88} \mathrm{Sr} /{ }^{44} \mathrm{Ca}$ and ${ }^{138} \mathrm{Ba} /{ }^{44} \mathrm{Ca}$ was significant within each separate tissue (Figure 4A). The significant correlation in all tissues shows the close connection of the ${ }^{88} \mathrm{Sr} /{ }^{44} \mathrm{Ca}$ and ${ }^{138} \mathrm{Ba} /{ }^{44} \mathrm{Ca}$ ratios. The lowest correlation, though still significant, was found in enamel.

A.
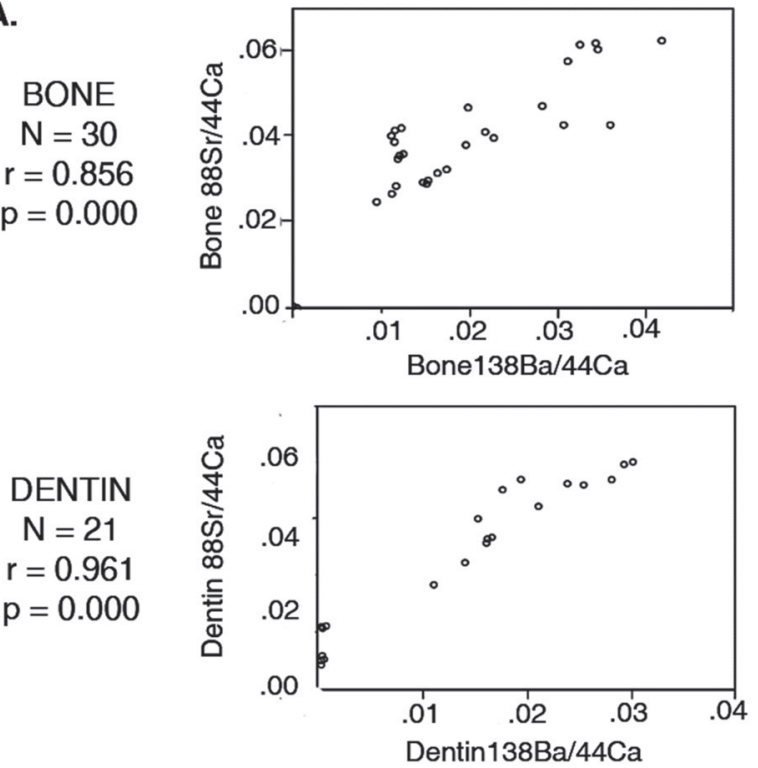

ENAMEL

$\mathrm{N}=22$

$r=0.485$

$p=0.022$

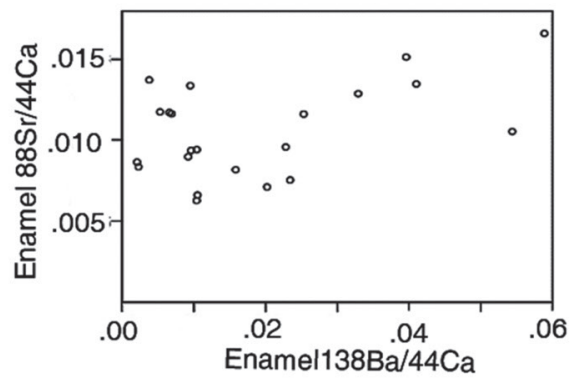

In Table 4, we present additional measurements within each individual according to the type of tissue. All individuals were compared with a pig bone (Sus scrofaf. domestica) that originated from the same site and same stratigraphy. Figure 4B shows significant differences in the ratio of ${ }^{88} \mathrm{Sr} /{ }^{44} \mathrm{Ca}$ $(\mathrm{N}=69$; Kruskal-Wallis $=35.02, \mathrm{df}=2 ; \mathrm{p}<0.05)$ and ${ }^{138} \mathrm{Ba} /{ }^{44} \mathrm{Ca}$ $(\mathrm{N}=65$; Kruskal-Wallis $=28.76, \mathrm{df}=2 ; \mathrm{p}<0.05)$ by tissue. In

B.
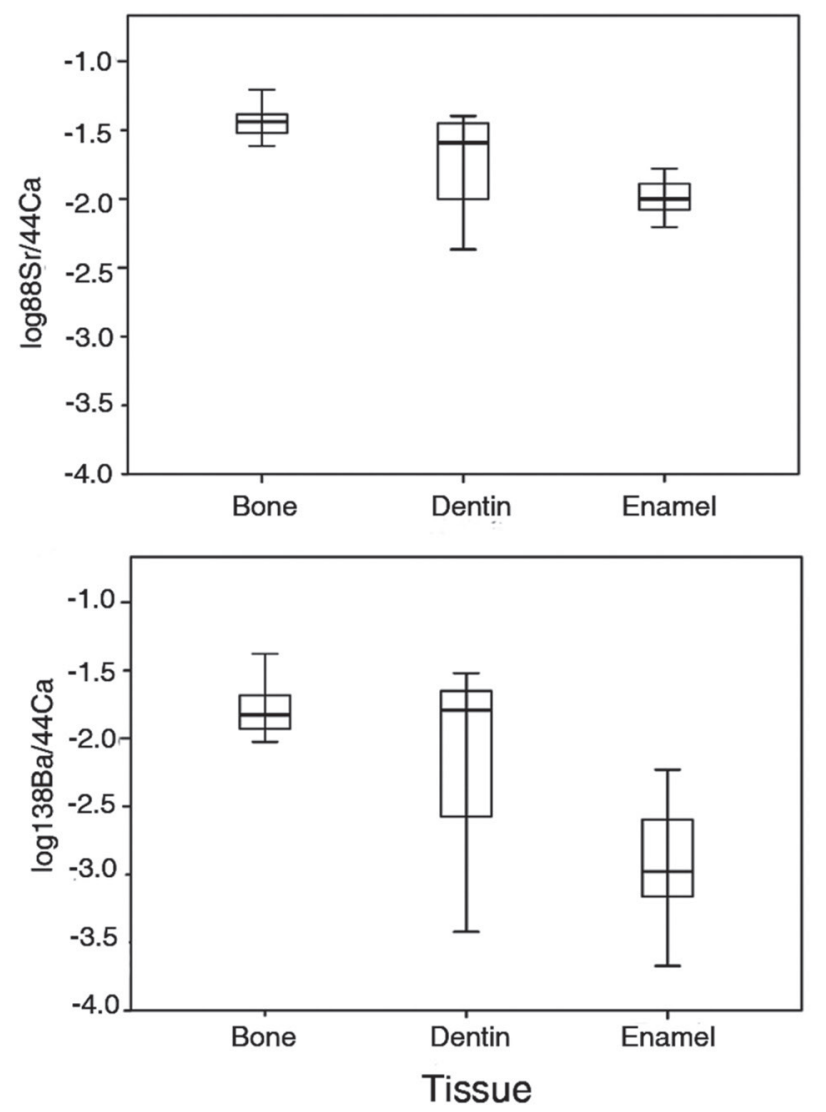

Figure 4. Isotopic correlation by tissue and different responses in each tissue. A: Correlation of ${ }^{88} \mathrm{Sr} /{ }^{44} \mathrm{Ca}$ and ${ }^{138} \mathrm{Ba} /{ }^{44} \mathrm{Ca}$ ratios by tissue; $\mathrm{B}$ : Different signal response of ${ }^{88} \mathrm{Sr} /{ }^{44} \mathrm{Ca}$ and ${ }^{138} \mathrm{Ba} /{ }^{44} \mathrm{Ca}$ ratios by tissue.

Table 4. Means, standard errors, and sample sizes, by tissue and individual. $\mathrm{N}=$ number of measurements in one individual.

\begin{tabular}{|c|c|c|c|c|c|c|c|c|c|c|c|c|c|}
\hline \multirow{3}{*}{ Individual ID } & \multirow{3}{*}{$\mathrm{n}$} & \multicolumn{4}{|c|}{ Bone } & \multicolumn{4}{|c|}{ Dentin } & \multicolumn{4}{|c|}{ Enamel } \\
\hline & & \multicolumn{2}{|c|}{${ }^{138} \mathrm{Ba} /{ }^{44} \mathrm{Ca}$} & \multicolumn{2}{|c|}{${ }^{88} \mathrm{Sr} /{ }^{44} \mathrm{Ca}$} & \multicolumn{2}{|c|}{${ }^{138} \mathrm{Ba} /{ }^{44} \mathrm{Ca}$} & \multicolumn{2}{|c|}{${ }^{88} \mathrm{Sr} /{ }^{44} \mathrm{Ca}$} & \multicolumn{2}{|c|}{${ }^{138} \mathrm{Ba} /{ }^{44} \mathrm{Ca}$} & \multicolumn{2}{|c|}{${ }^{88} \mathrm{Sr} /{ }^{44} \mathrm{Ca}$} \\
\hline & & Mean & SD & Mean & SD & Mean & $\mathrm{SD}$ & Mean & $\mathrm{SD}$ & Mean & SD & Mean & $\mathrm{SD}$ \\
\hline 107 & 4 & 0.013 & 0.005 & 0.031 & 0.010 & 0.014 & 0.003 & 0.022 & 0.004 & 0.001 & 0.000 & 0.010 & 0.003 \\
\hline 194 & 4 & 0.012 & 0.001 & 0.040 & 0.002 & 0.018 & 0.002 & 0.034 & 0.004 & 0.001 & 0.000 & 0.009 & 0.000 \\
\hline 230 & 4 & 0.012 & 0.001 & 0.035 & 0.001 & 0.001 & 0.001 & 0.011 & 0.001 & 0.005 & 0.000 & 0.014 & 0.003 \\
\hline 374 & 4 & 0.018 & 0.004 & 0.034 & 0.005 & 0.019 & 0.004 & 0.030 & 0.005 & 0.002 & 0.001 & 0.006 & 0.002 \\
\hline 229 & 4 & 0.036 & 0.005 & 0.061 & 0.002 & 0.028 & 0.002 & 0.038 & 0.002 & 0.001 & 0.000 & 0.012 & 0.001 \\
\hline 196 & 5 & 0.018 & 0.003 & 0.033 & 0.005 & 0.001 & 0.001 & 0.006 & 0.001 & 0.003 & 0.001 & 0.010 & 0.003 \\
\hline $\begin{array}{l}\text { Pig (Sus scrofa } \\
\text { f. domestica) }\end{array}$ & 4 & 0.032 & 0.003 & 0.048 & 0.009 & - & - & - & - & - & - & - & - \\
\hline
\end{tabular}

$\mathrm{n}=$ number of measurements in one individual. 
Table 5. Pairwise comparison between samples.

\begin{tabular}{lcccccc}
\hline & & & & \multicolumn{3}{c}{${ }^{{ }^{88} \mathbf{S r} \mathbf{B a}{ }^{44} \mathbf{C a}}{ }^{44} \mathbf{C a}$} \\
\hline Sample vs. Sample & Test Statistic* & SE & p value & Test Statistic* & SE & p value \\
\hline Enamel-dentin & 13.723 & 5.98 & 0.022 & 22.852 & 5.92 & 0.000 \\
Enamel-bone & 34.678 & 5.92 & 0.000 & 28.689 & 5.58 & 0.000 \\
Dentin-bone & 20.955 & 5.85 & 0.000 & 5.838 & 5.80 & $0,315^{* *}$ \\
\hline
\end{tabular}

*Kruskal-Wallis test

**"null hypothesis is accepted; the ratio distribution is the same in the samples

both observations, the lowest value of each ratio was found in enamel and the highest one in bone. In dentin, there was the widest range of values caused by the variability among the individuals. However, the means between dentin and bone were similar for ${ }^{138} \mathrm{Ba} /{ }^{44} \mathrm{Ca}$. When we combined the values from enamel and dentin together, there was no effect on the values of dentin, because of the low signals in enamel.

We used a pairwise comparison as per the Kruskal-Wallis test. The ${ }^{138} \mathrm{Ba} /{ }^{44} \mathrm{Ca}$ distribution was the same across dentin and bone (Table 5), otherwise all other combinations differed significantly by tissue.

Figure 5 presents the mean intensity ratios of ${ }^{88} \mathrm{Sr} /{ }^{44} \mathrm{Ca}$ and ${ }^{138} \mathrm{Ba} /{ }^{44} \mathrm{Ca}$ by individuals and tissue. While these results were difficult to extrapolate due to the small sample size, it seems that enamel deviated significantly from bone and dentin in both ratios. Values were usually lower in dentin than in bone, and in enamel than in dentin and bone. Higher intensity ratios in dentin can be explained by biogenic factors. The enamel values significantly deviated from dentin although their development was simultaneous. Intensity ratios found in enamel are similar to the bones of carnivores (for example, according to Burton et al. 1999). Overall, ${ }^{138} \mathrm{Ba},{ }^{88} \mathrm{Sr}$ and ${ }^{44} \mathrm{Ca}$ intensities were very low in enamel and, in connection with the lowest correlation of both ratios in enamel, these values possibly do not reflect the biogenic signal.

However, there were interesting correlations found in the bone and dentin. For example, the third molar of individual 229, a young adult female, showed higher intensity ratios of both elements in both dentin and bone. It was expected that data on diet obtained from both the tooth and bone would be in accord, as they reflected a similar episode in the individual's life (i.e. the mineralization of the third molar was variable, but more or less synchronous in a juvenile). Dentin data were similar for individuals 196 and 230, as both were derived from the second permanent molar whose mineralization occurs broadly between 2 and 5 years of age. In the remaining individuals, the first molars were analysed. These precede the second molars mineralize prior to three years of age. The lower values of ${ }^{88} \mathrm{Sr} /{ }^{44} \mathrm{Ca}$ in $\mathrm{M} 1$ compared to M3 are to be expected, since the M1 may have been affected by lactating and thus had a higher trophic level (Austin et al. 2013). The lower values in teeth, compared to bone, could be expected for the same reasons.

Figure 6 shows the clusters of individuals based on their isotopic signals, which are individually specific. All individuals (100\%) from the reference groups were classified correctly. However, bone and dental tissues classified individuals with varying degrees of reliability. Isotopic signals from bone tissue classified individuals less $(83.33 \%)$ than dental tissue $(100 \%)$. Using a cross validation (Jackknife) method, the correct classification rate was $66.67 \%$ in bone and $95.83 \%$ in enamel and dentin.

\section{Discussion}

The intensities of the isotopes significantly differ by tissue and by individual. They are highest in bone, and lowest in enamel. There is a similar ratio signal between bone and dentin, while the enamel is different from both. Correlation
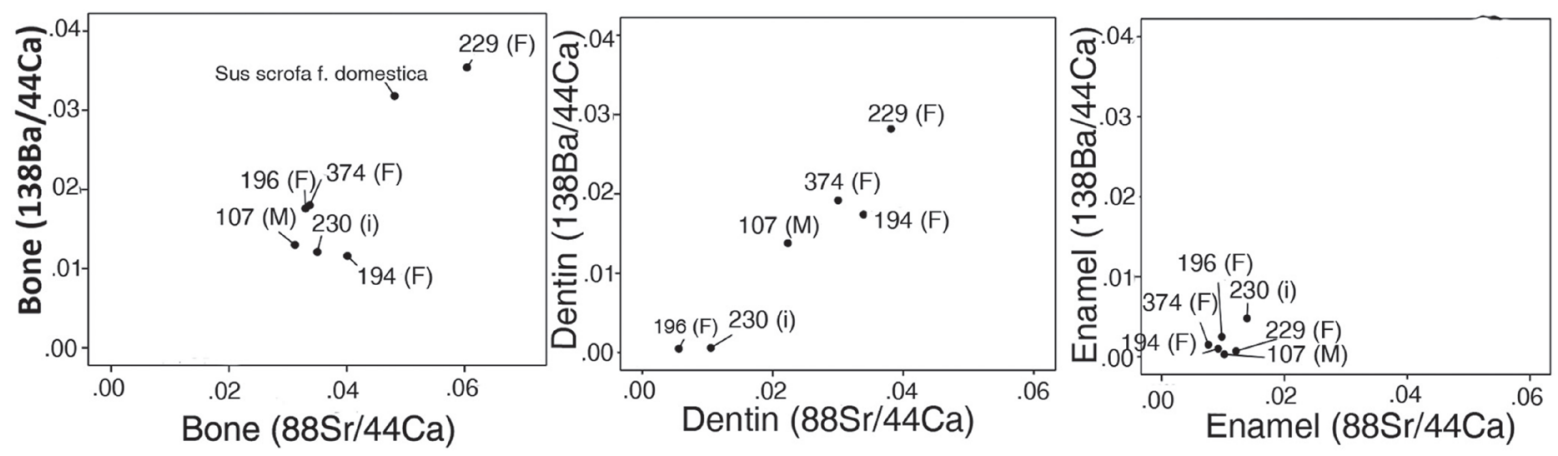

Figure 5. Distribution of ${ }^{88} \mathrm{Sr} /{ }^{44} \mathrm{Ca}$ and ${ }^{138} \mathrm{Ba} /{ }^{44} \mathrm{Ca}$ ratios according to individuals within each tissue. Scatter plots showing distribution, by individual and by tissue. Bone is compared against pig (Sus scrofa f. domestica). $\mathrm{F}=$ female; $\mathrm{M}=$ male; i=indifferent individual. 


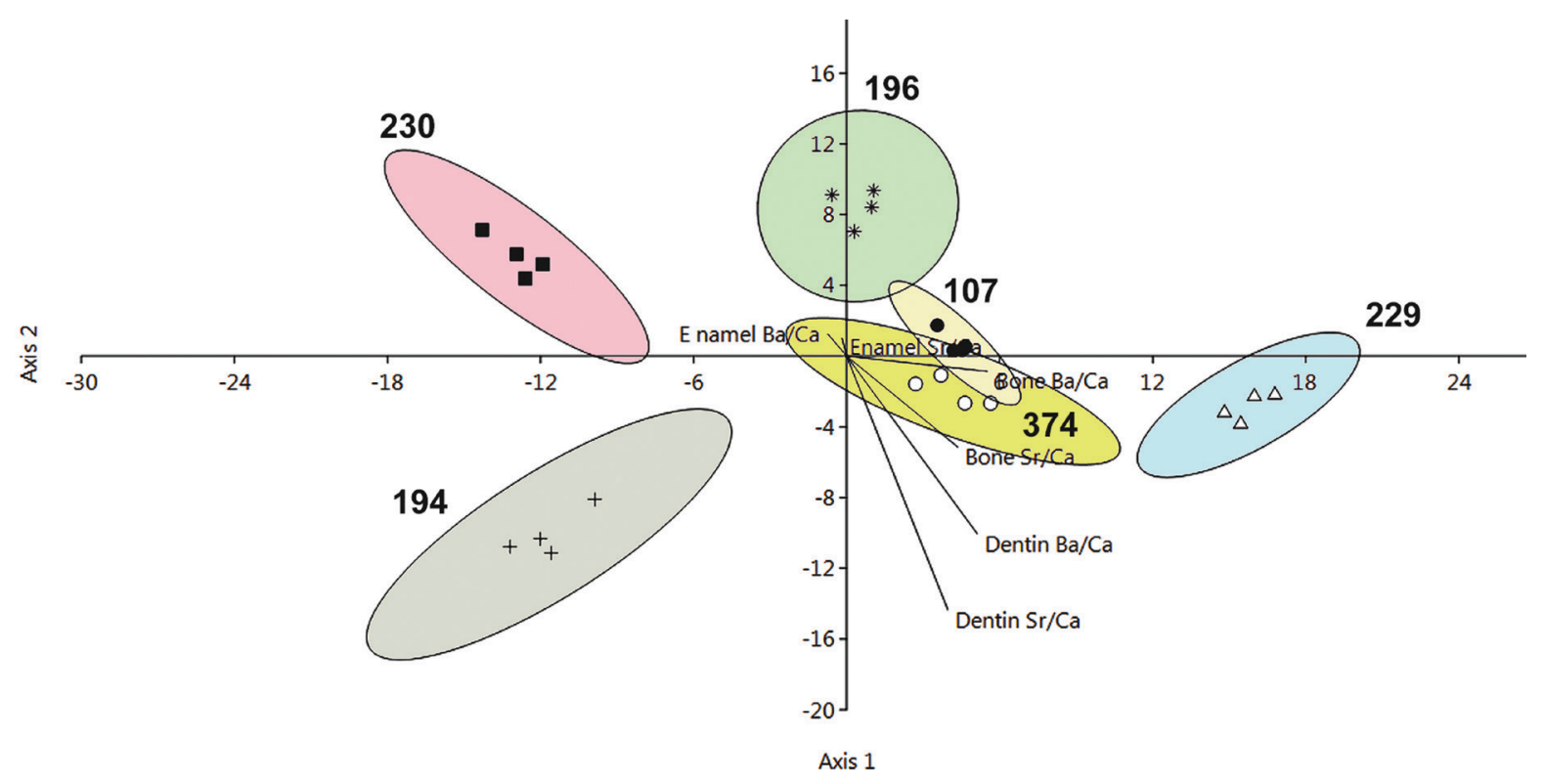

Figure 6. Linear discriminant analysis (LDA) scatter plot. Scatter plot shows clusters of individuals according to ${ }^{88} \mathrm{Sr} /{ }^{44} \mathrm{Ca}$ and ${ }^{138} \mathrm{Ba} /{ }^{44} \mathrm{Ca}$ ratios in hard tissue; $\mathrm{n}=25$ measurements (in six individuals).

of both ratios $\left({ }^{88} \mathrm{Sr} /{ }^{44} \mathrm{Ca}\right.$ and $\left.{ }^{138} \mathrm{Ba} /{ }^{44} \mathrm{Ca}\right)$ was significant within each tissue, but less significant in enamel. The positive correlation, however, shows that all tissues followed similar processes (biogenic and diagenetic) as indicated by both ratios. Furthermore, the intensities of the isotopes classified individuals into clusters and it is apparent that the isotope signals reflect more an individual's incorporation of minerals and absorption of elements from their diet rather than their general dietary pattern. Although the ratios are lower in dentin, they are similarly distributed in all individuals, similar to that in bone. In both cases, individual 229 stands out, with high values of both ${ }^{88} \mathrm{Sr} /{ }^{44} \mathrm{Ca}$ and ${ }^{138} \mathrm{Ba} /{ }^{44} \mathrm{Ca}$ ratios, caused by a poorer Ca signal when compared to individuals 374, 194 and 107. All have similar intensities of ${ }^{138} \mathrm{Ba}$ and ${ }^{88} \mathrm{Sr}$. Individuals 230 and 196 are anomalous in their signal for dentin. Individual 230 shows a decline of ${ }^{44} \mathrm{Ca}$ and ${ }^{88} \mathrm{Sr}$ over time, possibly caused by a variable deposition of the elements. ${ }^{44} \mathrm{Ca}$ was low in both individuals (lower than in individual 229). Individual 230, however, showed high ${ }^{88} \mathrm{Sr}$ values. Traces of $\mathrm{Ba}$ were comparatively very low in both individuals. The growth of ${ }^{88} \mathrm{Sr}$ and decline of ${ }^{44} \mathrm{Ca}$ may also reflect some contamination. However, when we measured the elements' concentration with $\mathrm{pXRF}$ in all samples, the $\mathrm{Ca} / \mathrm{P}$ ratio was 2.20: meaning the skeletons were not influenced by contamination during their deposition.

We suppose that the reason for the variation in isotopic signals is each individual's incorporation of minerals into their hard tissue. Recent studies (Gonzalez-Rodriguez, Fowler 2013; Perrone et al. 2014) have used X-ray fluorescence spectrometry (XRF) for discriminating human remains by analyzing the element concentration in bones. During one individual's life the bones are sculpted by process modelling, which allows the formation of new bone. Most of an adult's skeleton is replaced every 10 years or so (Currey 2002).
During remodelling, new minerals are incorporated into the formation of bone and partially into dentin. However, the dentin mineral is remodelled to a much lesser extent and the remodelling is under cellular control (Boskey 2007). Enamel, by contrast, does not remodel itself and retains the isotopes of elements incorporated at the time of its formation. Individual skeletal mineral composition is associated with uptake from the diet, water, metabolic function, inhalation, and environment exposure of an individual, as well as with specific tissue formation during development in utero (Dolphin et al. 2005). Darrah (2009) has shown that trace element incorporation occurs systematically according to predictable physiochemical parameters. Elements that are not strongly affected by metabolic activity (e.g. Ba and Sr) may be directly linked to individual dietary inputs. Trace elements differ in relation to individuality and may thus be also useful for forensic studies (Perrone et al. 2014).

In addition, diagenetic processes also affect the element concentration individually. Barium and strontium are located in group II of the periodic table along with calcium. These elements substitute for calcium in hydroxyapatite, the mineral component of bone. LA ICP-MS is, however, well suited to detect contamination (Prohaska et al. 2002). Its high spatial resolution makes it possible to analyse isotope ratios in selected regions of the teeth and detect altered zones. Contamination may come from, for example, a crack in the tooth or from many other factors (Hedges 2002). With the ablation, a significant drop of intensities in individual 230 was recorded and the value discarded. Contamination can be ruled out as a cause of the variability as it would have to influence all the isotopes in the same way to preserve the correlations we presently observe. The correlation between the ratios does not imply just a degree of bio-purification but also the exposure to diagenetic processes. Diagenesis alters 
bone ratios towards an equilibrium with soil ratios, so there is no guarantee that the bone $\mathrm{Ba} / \mathrm{Ca}$ and $\mathrm{Sr} / \mathrm{Ca}$ ratios remain correlated (Burton et al. 1999).

Another issue is the differences in mineral absorption by hard tissue. The intake of elements in enamel is lower than in dentin and bones (Eggins et al. 2003). The intake of $\mathrm{Ca}$ increases during mineralization at the expense of $\mathrm{Ba}$ and $\mathrm{Sr}$ so that these latter two are less represented in enamel and dentin (Balter 2004). Though tooth tissue is resistant due to its high mineralization, and conserves ontogenetic information, it can show higher chemical variability depending on the changes over a person's lifetime. Element distributions in one tooth may be more variable than between several teeth of one individual. This is caused by the chronology of individual development, the degree of mineralization in different periods of a person's life, their diet, stress and diseases (Dolphin et al. 2005). The chemical composition of dentin is largely influenced by the life-long deposition of elements, and related to gender and age (Kumagai et al. 2012). As well as differences in Sr concentrations having been observed between the sexes (Li et al. 2013), positive correlations have been observed between Sr concentrations and an individuals' age (Kumagai et al. 2012).

Another significant factor is the analysis of the tissues, and the ability to distinguish between natural isotopic composition and numerical values influenced by methodology. Laser ablation ICP-MS measurement is influenced by unequal ablation and by the differential vaporization of isotopes in plasma. Because of the values of certain isotopes depended to a certain extent on the time of measurement, the signal could be variable during measurement, dropping in any particular moment due to inhomogeneity. However, such anomalies were deleted. Nonetheless, signals of certain isotopes fluctuated over time in individuals. In dentin, the signal remained relatively constant over time, whilst in enamel it fluctuated more strongly, so that enamel suffered major deviations in its record. Fluctuations in enamel may be caused by the inhomogeneous distribution of elements in the material, and by its hardness influencing the rate of vaporization.

\section{Conclusion}

This study shows that there is high variability in the isotopic response of skeletal tissue. Great care must be taken when interpreting isotope measurement results to reconstruct diet and geographic origins. Many other factors, such as biogenic processes, diagenetic alteration and ablation have been shown to bias the data. Our results indicate that isotope signals in human hard tissue serve rather better as a chemometric tool than as a tool for dietary pattern reconstruction. Furthermore, enamel deviates isotopically from bone and dentin. The reason for this deviation may be the inability of enamel to be remodelled during an individual's life: we are thus unable to detect individual metabolic function, diet pattern, and mineral incorporation. The enamel also records the episodes of growth and development of an individual, as these episodes are characterized by variability in their exposure to chemical elements. Stress and diseases can leave typical traces in enamel in the form of defects and undermineralization. Another reason for this enamel deviation may be due to its hardness and the "noisy" signal of its isotopes during ablation. Furthermore, enamel is also not immune to the diagenetic processes. It can be structurally and isotopically altered just as much as other tissues.

The analysis of isotope ratios in human skeletal remains must take into account the complex and unique chemical, diagenetic, biogenic and ablative properties of different tissue types. Without the careful integration of primary and secondary corroborating evidence, significant unintended bias in the interpretation of bioarchaeological data will result from straightforward laser ablation-ICP-MS analysis.

\section{Acknowledgement}

The authors gratefully acknowledge the support by the project POSTOC-16 (University of West Bohemia, Pilsen) and Ministry of Education Youth and Sports of the Czech Republic (projet LO 1305). We would like to thank Martin Paulus and Arkadiusz Tajer from the Archaeological Centre in Olomouc and Martin Moník for their help.

\section{References}

ARNAY-DE-LA-ROSA, M., GONZÁLEZ-REIMERS, E., GÁMEZMENDOZA, A., GALINDO-MARTÍN, L. 2009: The $\mathrm{Ba} / \mathrm{Sr}$ ratio, carious lesions, and dental calculus among the population buried in the church La Concepción (Tenerife, Canary Islands). Journal of Archaeological Science 36, 351-358.

ALLMÄE, R., LIMBO-SIMOVART, J., HEAPOST, VERŠ, E. 2012: The content of chemical elements in archaeological human bones as a source of nutrition research. Papers on Anthropology 2, 27-49.

ALVIRA, F., RAMIREZ ROZZI, F., TORCHIA, G., ROSO, L., BILMES, G. 2011: A new method for relative Sr determination in human teeth enamel. Journal of Archaeological Science 89, 153-160.

ALVIRA, F.C., RAMIREZ ROZZI, F., BILMES, G.M. 2010: LaserInduced Breakdown Spectroscopy Microanalysis of Trace Elements in Homo sapiens Teeth. Applyed Spectroscopy 64, 313-319.

AUSTIN, C., SMITH, T.M., BRADMAN, A., HINDE, K., JOANNESBOYAU, R., BISHOP, D., HARE, D.J., DOBLE, P., ESKENAZI, B., ARORA, M. 2013: Barium distributions in teeth reveal early-life dietary transitions in primates. Nature 498, 216-219.

BALTER, V. 2004: Allometric constraints on $\mathrm{Sr} / \mathrm{Ca}$ and $\mathrm{Ba} / \mathrm{Ca}$ partitioning in terrestrial mammalian trophic chains. Oecologia 139: 83-88.

BALTER, V., SIMON, L. 2006: Diet and behavior of the Saint-Cesaire Neanderthal inferred from biogeochemical data inversion. Journal of Human Evolution 51, 329-338.

BARKER, G. 1985: Prehistoric Farming in Europe. Cambridge University Press, Cambridge.

BENTLEY, R.A. 2004: Characterising human mobility by strontium isotope analysis of the skeletons. In: Higham, C. F. W., Thosarat, R. (Eds.) Khok Phanom Di: summary and conclusions. Oxbow, Oxford, 159-66.

BRÜGMANN, G., KRAUSE, J., BRACHERT, T. C., STOLL, B., WEIS, U., KULLMER, O., SSEMMANDA, I., AND MERTZ, D. F. 2012: Chemical composition of modern and fossil hippopotamid teeth and implications for paleoenvironmental reconstructions and enamel formation - Part 2: Alkaline earth elements as tracers of watershed hydrochemistry and provenance. Biogeosciences 9, 4803-4817. 
BOSKEY, A. 2007: Mineralization of Bones and Teeth. Elements 3 (6), 385-391.

BURTON, J. 2007: Bone Chemistry and Trace Element Analysis. In: Ambrose, A. S., Katzenberg, M. A. (Eds): Biological Anthropology of the Human Skeleton, John Wiley \& Sons, Inc., New York, 443-460.

BURTON, J., PRICE, T. D. 2002: The Use and Abuse of Trace Elements for Paleodietary Research. In: Ambrose, A. S., Katzenberg, M. A. (Eds): Biogeochemical Approaches to Paleodietary Analysis. New York, Springer US, 159-171.

BURTON, J. H. 1996: Trace elements in bone as paleodietary indicators. In: Orna, M.V. (Ed): Archaeological Chemistry: Organic, Inorganic and Biochemical Analysis, Symposium Series 625. American Chemical Society, Washington DC, 327-333.

BURTON, J. H., PRICE, T. D. 1990: The ratio of barium to strontium as a paleodietary indicator of consumption of marine resources. Journal of Archaeological Science 17, 547-557.

BURTON, J. H., PRICE, T. D., CAHUE, L., WRIGHT, L. E. 2003: The Use of Barium and Strontium Abundances in Human Skeletal Tissues to Determine their Geographic Origins. International Journal of Osteoarchaeology 13, 88-95.

BURTON, J. H., PRICE, T. D., MIDDLETON, W. D. 1999: Correlation of Bone $\mathrm{Ba} / \mathrm{Ca}$ and $\mathrm{Sr} / \mathrm{Ca}$ due to Biological Purification of Calcium. Journal of Archaeological Science 26, 609-616.

BURTON, J. H., WRIGHT, L. E. 1995: Nonlinearity in the relationship between bone $\mathrm{Sr} / \mathrm{Ca}$ and diet: paleodietary implications. American Journal of Physical Anthropology 96, 273-282.

COPELAND, S. R., SPONHEIMER, M., LE ROUX, P. J., GRIMES, V., LEE-THORP, J. A., DE RUITER, D. J., RICHARDS, M. P. 2008 Strontium isotope ratios $(87 \mathrm{Sr} / 86 \mathrm{Sr})$ of tooth enamel: a comparison of solution and laser ablation multicollector inductively coupled plasma mass spectrometry methods. Rapid Communications in Mass Spectrometry 22(20), 3187-3194.

COPELAND, S. R., SPONHEIMER, M., LEE-THORP, J. A., LE ROUX, P. J., DE RUITER, D. J., RICHARDS, M. P. 2010: Strontium isotope ratios in fossil teeth from South Africa: assessing laser ablation MCICP-MS analysis and the extent of diagenesis. Journal of Archaeological Science 37(7), 1437-1446.

CURREY, J. D. 2002: Bones: Structure and Mechanics. Princeton University Press, New Jersey.

DARRAH, T. H., 2009: Inorganic trace element composition of modern human bones relation to bone pathology and geographical provenance. MS. Unpublished dissertation thesis. Deposited: University of Rochester Department of Earth and Environmental Sciences, Rochester (UK).

DOLPHIN, A. E., GOODMAN, A. H., AMARASIRIWARDENA, D. D. 2005: Variation in elemental intensities among teeth and between pre- and postnatal regions of enamel. American Journal of Physical Anthropology $128,878-888$

EGGINS, S., GRÜN, R., PIKE, A. W. G., SHELLEY, M., TAYLOR, L. 2003: 238U, 232Th profiling and U-series isotope analysis of fossil teeth by laser ablation-ICPMS. Quaternary Science Reviews 22, 1373-1382.

EZZO, J. A., LARSEN, C. S., BURTON, J. H. 1995: Elemental signatures of human diets from the Georgia Bight. American Journal of Physical Anthropology 98, 471-481.

GEMMEL, A., TAVARES, M., ALPERIN, S., SONCINI, J., DANIEL, D., DUNN, J., CRAWFORD, S., BRAVEMAN, N., CLARKSON, T. W., MCKINLAY, S., BELLINGER, D. C. 2002: Blood lead level and dental caries in school-age children. Environmental Health Perspectives $110,625-630$.

GONZALEZ-RODRIGUEZ, J., FOWLER, G., 2013: A study on the discrimination of human skeletons using X-ray fluorescence and chemometric tools in chemical anthropology. Forensic Science International 231, 1-3.

HAMMER, Ø., HARPER, D. A. T., RYAN, P. D., 2001. PAST: Paleontological statistics software package for education and data analysis. Palaeontologia Electronica 4(1), 9.

HEDGES, R. E. M. 2002: Bone diagenesis: An overview of processes. Archaeometry 44, 319-328.

HOLUB, M. 2010: Chráštany, trat' Záhumení. MS. Excavation report (zooarchaeological analysis), nr. 30/2008. Deposited: Archeologické centrum Olomouc (282/11).
KANG, D., AMARASIRIWARDENA, D., GOODMAN, A. H. 2004: Application of laser ablation-inductively coupled plasma-mass spectrometry (LA-ICP-MS) to investigate trace metal spatial distributions in human tooth enamel and dentine growth layers and pulp. Analytical and Bioanalytical Chemistry 378, 1608-1615.

LEWIS, J., COATH, C. D., PIKE, A. W. G. 2014: An improved protocol for $87 \mathrm{Sr} / 86 \mathrm{Sr}$ by laser ablation multi-collector inductively coupled plasma mass spectrometry using oxide reduction and a customised plasma interface. Chemical Geology 390, 173-181.

LI, Z., HE, M., PENG, B., JIN, Z. 2013: Strontium concentrations and isotope ratios in enamel of healthy and carious teeth in southern Shaanxi, China. Rapid Commun Mass Spectrom. 15, 1919-1924.

KOČÁROVÁ, R., KOČÁR, P. 2010: Chráštany (okr. Kroměříž). Excavation report (archaeobotanical analysis), nr. 39/2010. Deposited: Archeologické centrum Olomouc (282/11).

KOHN, M. J., SCHOENINGER, M. J., BARKER, W. W. 1999: Altered states: Effects of diagenesis on fossil tooth chemistry. Geochimica Et Cosmochimica Acta 63, 2737-2274.

KUMAGAI, A., FUJITA, Y., ENDO, ITAI, K. 2012: Concentrations of trace element in human dentin by sex and age. Forensic Science International 219, 29-32.

MALARA, P., KWAPULINSKI, J., MALARA, B. 2006: Do the levels of selected metals differ significantly between the roots of carious and noncarious teeth? Science of The Total Environment 369, 59-68.

MÜLLER, V. 1994: Vysvétlivky k souboru geologických a účelových map prírodnich zdroju 1:50 000, List 25-31 Kroměříž. Český geologický ústav, Praha.

PAULUS, M. 2011: Chrášt’any. Excavation report, nr. 282/2011. Deposited in: Archeologické centrum Olomouc.

PERRONE, A., FINLAYSON, J. E., BARTELINK, E. J., DALTON, K. D., 2014: Application of Portable X-ray Fluorescence (XRF) for Sorting Commingled Human Remains, In: Byrd, J., Adams, B. (Eds.): Commingled Human Remains, Academic Press, San Diego, 145-165.

PATTERSON C. C., ERICSON J., MANEA-KRICHTEN M., SHIRAHATA H. 1991: Natural skeletal levels of lead in Homo sapiens sapiens uncontaminated by technological lead. Sci. Total Environ. 107, 205-236.

PHARSWAN, J. S., FARSWAN, Y. S. 2011: Role and utility of trace elements in palaeodietary reconstruction. New York Science Journal 4, 43-48.

PROHASKA, T., LATKOCZY, C., SCHULTHEIS, TESCHLERNICOLA, M, STINGEDER, G. 2002: Investigation of $\mathrm{Sr}$ isotope ratios in prehistoric human bones and teeth using laser ablation ICPMS and ICP-MS after Rb/Sr separation. Journal of Analytical Atomic Spectrometry 17, 887-891.

REYNARD, L. M., HENDERSON, G. M., HEDGES, R. E. M. 2011: Calcium isotopes in archaeological bones and their relationship to dairy consumption. Journal of Archaeological Science 38, 657-664.

SILLEN, A. 1988: Elemental and isotopic analyses of mammalian fauna from Southern Africa and their implications for paleodietary research. American Journal of Physical Anthropology 76, 49-60.

SPONHEIMER, M., DE RUITER, D., LEE-THORP, SPÄTH, A. 2005: $\mathrm{Sr} / \mathrm{Ca}$ and early hominin diets revisited: new data from modern and fossil tooth enamel. Journal of Human Evolution 48, 147-156.

SPONHEIMER, M. B., LEE-THORP, J. A. 2006: Enamel diagenesis at South African Australopith sites: Implications for paleoecological reconstruction with trace elements. Geochimica et Cosmochimica Acta 70, 1644-1654.

SZOSTEK, K., GLAB, H., PUDLO, A. 2009: The use of strontium and barium analyses for the reconstruction of the diet of the early medieval coastal population of Gdansk (Poland): A preliminary study. Homo 60, 359-372.

URYU T., YOSHINAGA J., YANAGISAWA Y., ENDO M., TAKAHASHI J. 2003: Analysis of lead in tooth enamel by laser ablation-inductively coupled plasma-mass spectometry. Anal. Sci. 19, 1413-1416.

WENINGER, B., JÖRIS, O., DANZEGLOCKE, U. (2007). CalPal-2007. Cologne radiocarbon calibration \& palaeoclimate research package. Cologne. 
